\section{Spring 2009}

In this issue, we focus on renewable, electricity, and buildings technologies.

\section{New reference solar} spectrum changing how scientists evaluate solar cells

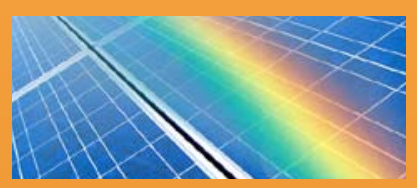

NREL inventions receive R\&D 100, Federal Laboratory Consortium awards

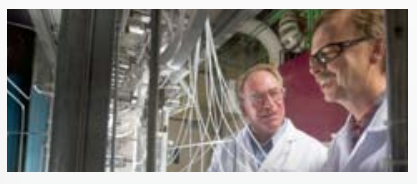

National Wind Technology Center prepares to install multimegawatt wind turbine

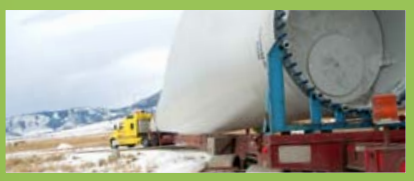

\section{Home of the Future Showcases Energy Efficiency}

The home at 607 Mormon St. in Folsom, California, looks like any other house on the tree-lined block. And yet, this three-bedroom bungalow is anything but normal. It's a Home of the Future-a home that blends technology and design to reduce utility bills and peak electric demand by $80 \%$.

The first product of the Home of the Future program - a partnership with the Sacramento Municipal Utility District (SMUD), the U.S. Department of Energy's National Renewable Energy Laboratory (NREL) and

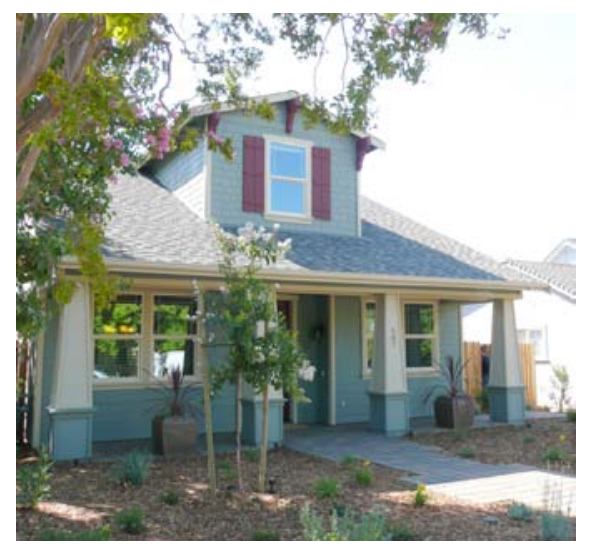

The traditional Craftsman look of this bungalow hides the technology that makes this one of the greenest homes in the United States. The home is rated LEED Platinum, and Green Builder Magazine selected it as its 2008 Home of the Year.
Building America program, and Building Science Corporation - the residence measures 1,921 square feet, with an additional 740 squarefoot guest quarters located above the garage.

"NREL's work with SMUD has helped both groups move toward the ultimate goal of zero-energy homes - homes that generate as much electricity as they use on an annual basis," said Ron Judkoff, Program Manager, NREL Buildings.

The owner of this home will save $\$ 1,400$ per year in utility costs when compared to homes that meet California's current, stringent standards. And, to help the environment, the Home of the Future has an $88 \%$ smaller carbon footprint.

Upon its completion in September 2008, the home received the U.S. Green Building Council's Leadership in Energy and Environmental Design $\left(\right.$ LEED $^{\circledR}$ ) Platinum designation. It also won Green Builder Magazine's Home of the Year award and is certified as an ENERGY STAR ${ }^{\circledR}$ home.

\section{Construction Details}

To reach these levels of energy savings, NREL used a whole-building integrated design approach and its Building Energy Optimization (BEopt)
“NREL's work with SMUD has helped both groups move toward the ultimate goal of zero-energy homes-homes that generate as much electricity as they use on an annual basis."

Ron Judkoff,

Program Manager, NREL Buildings

analytical software to determine the optimal design and construction for the hot and dry Sacramento climate. The home is made of environmentally friendly and energy-efficient building materials, including blown cellulose insulation, rigid foam, 2 in. x 6 in. stack framing, and an unvented attic design that keeps the air conditioner and ductwork within the structure.

The Home of the Future also includes solar thermal and photovoltaic (PV) collectors that conform to the shape of the roof. The home is connected to the utility grid to provide electricity when the sun's output is insufficient and to funnel excess energy back to the grid when sunlight is adequate. Modeling indicates the PV system will export about 2,000 kilowatt hours of electricity per year. 


\section{Additional Features}

The home includes many additional amenities that make it worthy of LEED Platinum certification-and truly the Home of the Future.

- Vinyl, low-e glass windows

- Automated window coverings that block UV rays by as much as $88 \%$

- Skylights for daylighting

- ENERGY STAR lighting and appliances

- Water-cooled evaporation air conditioner

- Ventilation system featuring MERV 13 air filters

- Low-volatile organic compounds interior paint

- Countertops made of recycled paper products and recycled bottles

- Flooring made with recycled or renewable materials.

\section{Home of the Future Program}

SMUD's Home of the Future program began in 2007 in an effort to partner with local builders and suppliers to create zero-energy homes. The idea was sparked because of the California Public Utility Commission's long-range energy strategy, which mandates that all new residential construction in the state must be zero net energy by 2020 .

Visit www.smudshomeofthefuture. org and www.nrel.gov/buildings/ residential.html to learn more.

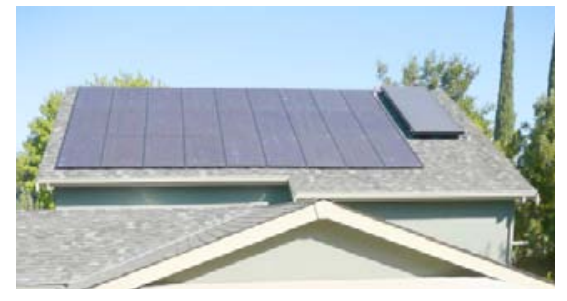

The back of the home features a 3.85 kilowatt rooftop photovoltaic system which, in conjunction with a solar thermal system and energy efficiency measures, helps reduce utility bills by $80 \%$.

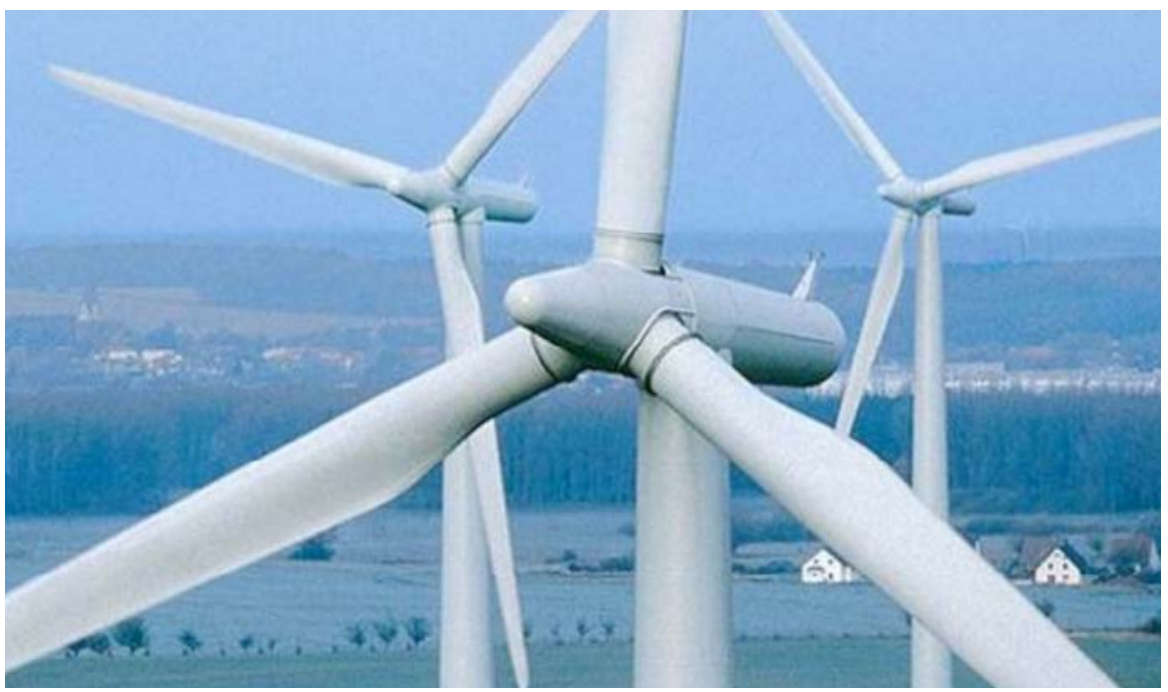

\section{NREL to Install Multimegawatt Turbines at NWTC}

If you combine $120 \mathrm{mph}$ winds with blinding snow, sleet, rain, or hail-and throw in a couple of lightning bolts for good measure-you will have an extreme environment that is perfect for validating a wind turbine's reliability and performance.

That's just one reason why Siemens Energy chose the National Renewable Energy Laboratory's National Wind Technology Center (NWTC) as the test site for its new 2.3-MW wind turbine. While it's rare to encounter all of these extreme weather conditions on the same day at the NWTC, the site's location just south of Boulder, Colorado, is ideal for testing wind turbines. The turbulent winds that sweep over the Rocky Mountains to blast the site during the fall and winter months and the smoother, more stable winds that blow in from the Great Plains during the spring and summer will provide Siemens with a diverse environment to test the structural integrity and performance of its new machine.

By the end of 2009, the NWTC will be home, at least temporarily, to both the Siemens 2.3-101 wind turbine and GE Energy's 1.5-MW turbine-the two largest turbines ever tested at the Lab.
With a rotor diameter of $101 \mathrm{~m}$, Siemens' new 2.3-MW wind turbine will provide more power at lower wind speeds.

Engineers at the NWTC will construct the foundations and infrastructure support needed for both the Siemens and the GE wind turbines during spring and summer 2009 so that both machines can be lifted into place when the huge crane required for installation arrives in September.

After the turbines are installed, both will be heavily instrumented to produce a constant stream of data to provide researchers with information to verify wind turbine performance. The Siemens turbine will provide data on the turbine's aerodynamics, power characteristics, vibrations, system fatigue, and acoustics. The data collected from this turbine will enable researchers to verify the performance of the turbine's new rotor in terms of power production, noise emission, and loads. The GE 1.5-MW turbine will mainly be used as a tool for long-term testing and R\&D. It will collect detailed data that will help researchers address a variety of issues, including wind farm underperformance and premature turbine component failure. In addition, it will be used for educational and outreach purposes. For more information about wind research at NREL, visit www.nrel.gov/wind/. 


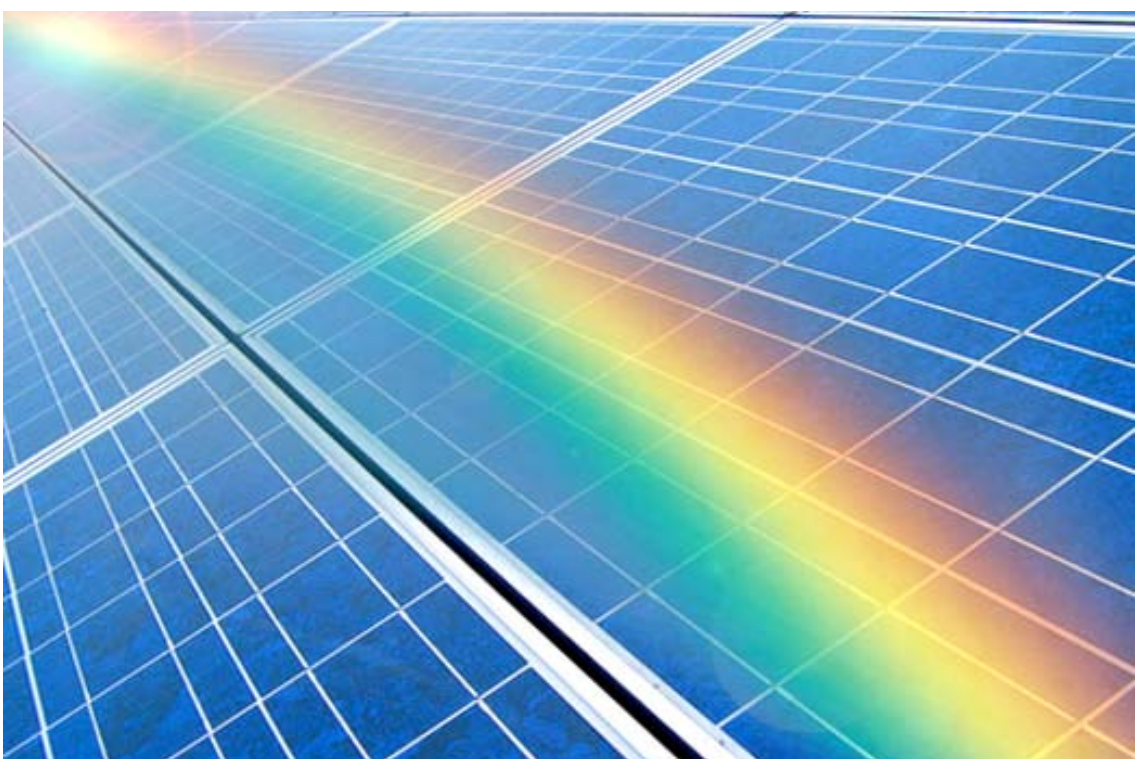

\section{NREL Develops New Reference Solar Spectrum}

NREL's new solar spectrum-used to test solar cell efficiency - is improving how the scientific community evaluates solar cell performance.

The new solar spectrum allows researchers to more accurately measure the energy conversion efficiencies of traditional solar cells and new solar technologies such as high-efficiency concentrator solar cells. It was developed by members of NREL's Measurements and Characterization and Solar Resource Assessment groups.

The rated performance of a solar panel is usually given as its peak wattage under a prescribed set of outdoor solar conditions. Typically, the higher the wattage rating, the more manufacturers charge for their solar panels because they deliver more watts per square meter. Testing involves bathing solar cells in a simulated solar spectrum to determine how well the material converts each wavelength of light in the spectrum into energy, including both visible and nonvisible light.
NREL's new reference solar spectrum is quickly becoming the standard for testing solar cells by solar companies worldwide.

The challenge is in the creation of the spectrum itself. The solar spectrum changes from space to earth and from location to location on earth. During testing, scientists must carefully calibrate and characterize their measured performance to an artificial standard reference solar spectrum to account for the differences between prevailing test conditions and the reference conditions. This allows performance measurements among various groups to be comparable.

NREL adopted the new spectrum in 2008; the rest of the world is in the process of changing now. NREL is working with solar companies worldwide to facilitate this process. Solar panel efficiency is tested in accordance with standards set by the International Electrotechnical Commission and the American Society for Testing and Materials. NREL is one of four laboratories in the world certified to test solar cell efficiencies in accordance with these standards. For more details, visit http://rredc.nrel.gov/solar/spectra/ am1.5/.

\section{NREL Hosts Wide Variety of VIP Guests}

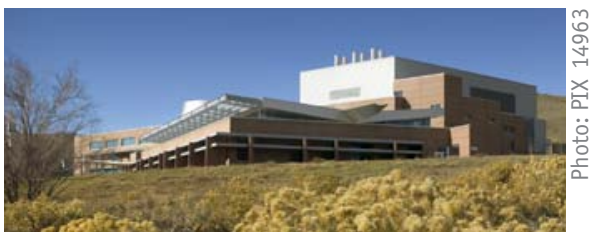

NREL continually attracts leaders in industry, government, and technology who are interested in learning more about its renewable energy research and technology innovations.

Recent VIP visits to NREL include: Electric Power Research Institute executives Dr. Steven R. Specker, $\mathrm{CEO}$ and President; Arshad Mansoor, Vice President, Power and Delivery \& Utilization; Bryan Hannegan, Vice President, Environment \& Generation; Clark Gellings, Vice President, Technology; and Dr. Michael W. Howard, Senior Vice President of Research and Development. For information about NREL's South Table Mountain site and the National Wind Technology Center, visit www.nrel.gov/wind."

\section{NREL Completes Plan to Retrofit Existing Buildings}

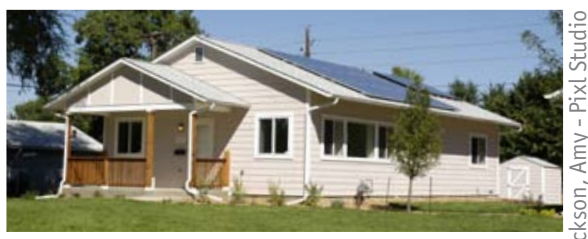

NREL researchers recently proposed an extensive plan for widespread energy efficiency retrofits in existing houses. The plan addresses a key initiative for the Department of Energy's Office of Energy Efficiency and Renewable Energy, as homes built before 1991 account for $82 \%$ of all energy consumption in the residential sector. Change to "Learn more at www. nrel.gov/buildings/residential.html." 


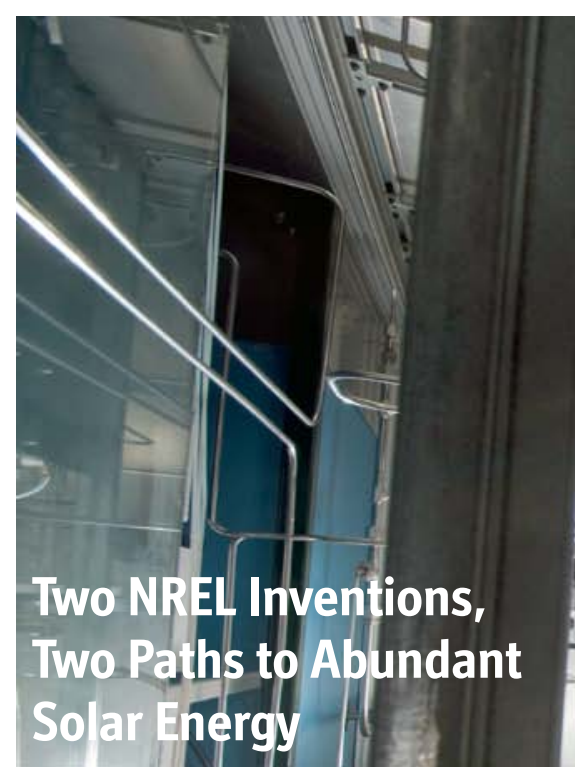

Two solar cell technologies invented and developed by NREL scientists are currently in the news. And they could not be more different-or more alike.

The inverted metamorphic multijunction (IMM) solar cell, invented by NREL Principal Scientist Mark Wanlass, consists of multiple layers of semiconductor material engineered in a way to capture energy from a major portion of the solar spectrum. Depending on how it is mounted, the IMM cell can be ultraflexible and lightweight, making it ideal for power applications in space. The cell's extremely high solarconversion efficiency of $40.8 \%$ (in laboratory conditions) and robust nature also make it a natural candidate for terrestrial use in large-scale solar power plants, where utilities will be able to generate electricity in the range of hundreds of megawatts to gigawatts.

NREL has partnered with industry leader Emcore Corp., which is well under way to commercializing the IMM technology. A second partner, Green Volts, signed on recently with plans to develop a customized IMM cell tailored to its optical system, accelerating the widespread commercialization and reducing the cost of the technology through its high-volume manufacturing partners.

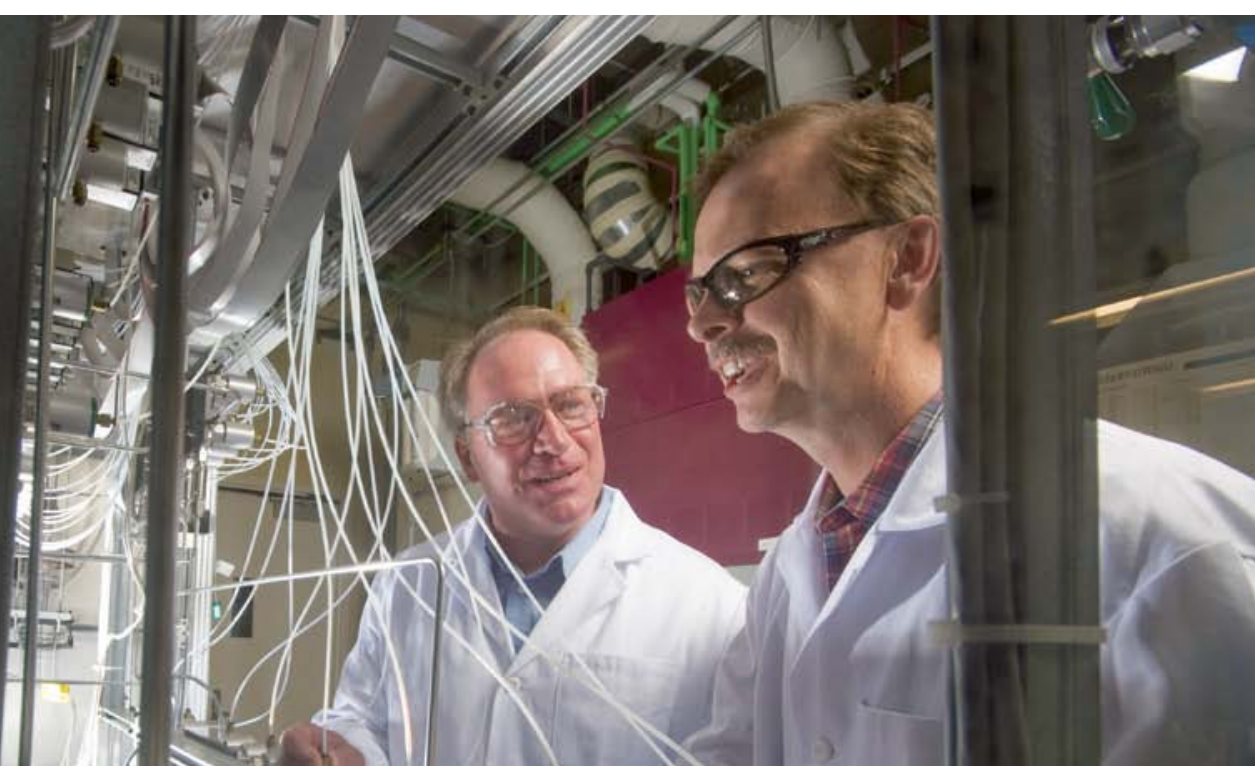

The second solar cell inventionhybrid CIGS technology-differs from the IMM cell in that it uses a process similar to printing to enable the direct inclusion of PV cells into common building materials. NREL Research Fellow David Ginley leads the team that developed the ink-based precursor technology used to manufacture hybrid CIGS. These cells are manufactured

\section{“These two technologies} represent a new wave of breakthroughs in development of solar cells that will have a significant impact on the penetration of solar energy in the marketplace."

Dan Arvizu, NREL Director

in layers by using ink-jet printing and ultrasonic spraying to precisely apply metal-organic inks in separate layers directly into common building materials such as metal and glass.

NREL's industry partner, HelioVolt Corp., developed a proprietary processing system that bonds the
Dr. Mark Wanlass, left, and Jeff Carapella have advanced the IMM solar cell at this National Center for Photovoltaics laboratory at NREL.

film layers under heat and pressure, forming large-grain CIGS crystals. The entire process takes only a few minutes. This simpler, combined approach could create enough of the flexible PV film to integrate it with windows, roofing, facades, and other structural components. These products could replace conventional building materials and turn buildings into small, self-sustaining power plants.

\section{How are the two technologies similar?}

Both earned R\&D 100 Awards in 2008 and shared honors as the "most revolutionary" technologies among all 2008 winners. Both won Federal Laboratory Consortium awards for "Excellence in Technology Transfer." And, through partnerships with industry allies, both technologies are leading the way to clean, abundant, cost-competitive electricity that is produced domestically. 


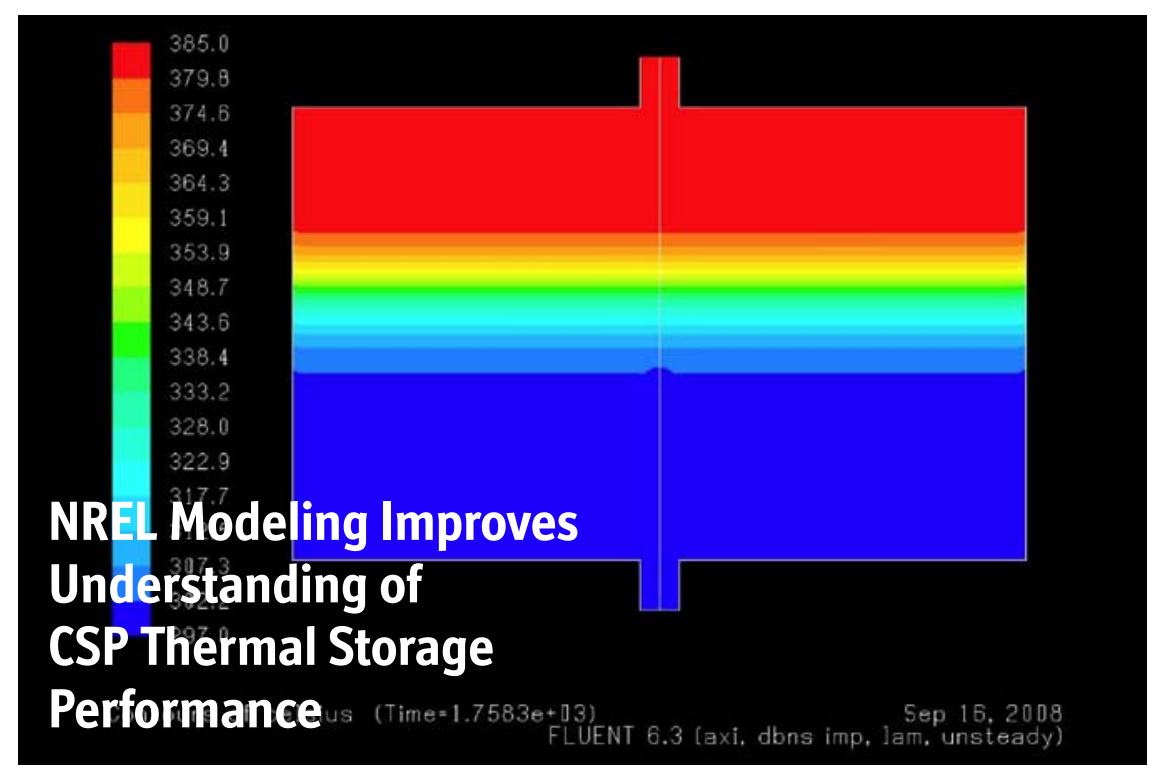

Parabolic trough concentrating solar power (CSP) systems have a major advantage over other renewable energy systems: an efficient means of storing energy for later use in generating electricity. But researchers want to know which thermal energy storage (TES) options provide the greatest technical and economic benefits.

One option being studied by Greg Glatzmaier and Desikan Bharathan, scientists in NREL's Concentrating Solar Power Subprogram (within the NREL Solar Program), is the singletank thermocline storage system. This system uses molten salt as the heat-transfer fluid, storing energy collected in the parabolic solar field and transferring that energy when needed to the same power-block heat exchangers served directly from the solar field.

In this system, the storage tank contains a hot, less-dense fluid zone at the top above a cooler, denser fluid zone at the bottom. A low-cost filler material that packs the tank serves as the primary thermal storage medium. It reduces the overall volume of more costly molten salt and prevents convective mixing in the tank.

\section{NREL Works to Strengthen Electric Power System}

Alternative energy sources will play an important role in our nation's energy portfolio only when the existing electricity grid can accommodate a wide range of distributed energy resources (DER) - such as photovoltaics, wind, fuel cells, micro turbines, and diesel generators or storage options such as batteries and flywheels.

"Distributed energy resources will cause a serious transformation of the electric power industry and the electric grid, which was not designed to accommodate alternative power generation and stored energy at the distribution level," said Richard DeBlasio, NREL Laboratory Program Manager for Electricity overseeing the NREL/DOE Distributed Energy and Electric Reliability Program and IEEE SCC21, and 1547 working group chair.

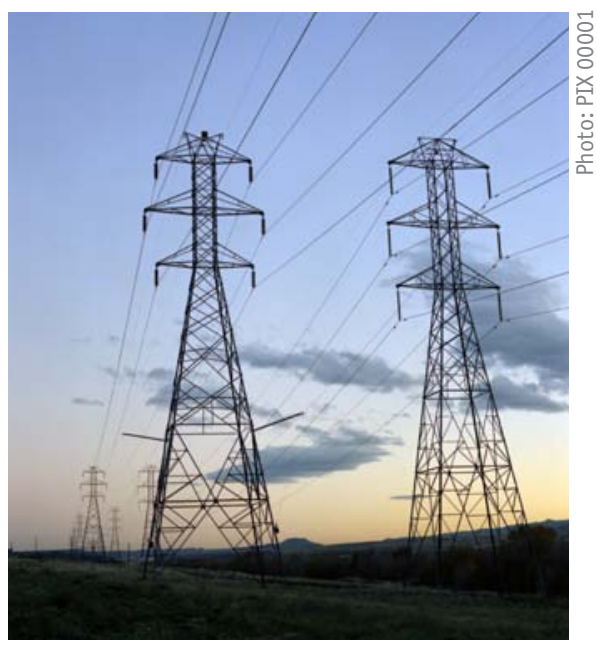

That's why NREL is working to strengthen the electric power system through electric infrastructure systems research and the development of standards that enable distributed generation, energy storage, and load control technologies to be integrated into electric power systems. 
When properly integrated, these technologies can improve electric reliability and grid security while decreasing power costs.

"Without harmonized standards and implementation at state, regional, and international levels, we can expect higher costs, less-efficient implementations, and semicustom design approaches to the interconnection of DER technologiesinstead of uniform and well-proven methods," said Thomas Basso, senior scientist at NREL and secretary of the IEEE Standards Coordinating Committee 21 and several IEEE standards working groups.

\section{IEEE Standards Involvement}

NREL has a long involvement with establishing requirements for grid integration-even prior to 2003 , when IEEE 1547, Standard for Interconnecting Distributed Resources with Electric Power Systems, was approved.

"This high-profile effort involved more than 350 participants from all aspects of the power industry - and represented a big accomplishment related to interconnection standards," DeBlasio said. "IEEE 1547 has evolved into 1547.1 through 1547.7, which are still very active. The initial approval of 1547 in 2003 was, and still is, monumental."

Today, NREL is working on IEEE standards and guidelines for the smart grid, including providing leadership for facilitating and accelerating the IEEE P2030 standards development project. The P2030 project, approved by the IEEE Standards Board on March 19, 2009, will help establish a sound engineering baseline for defining and understanding the smart grid and developing a body of standards. For more information about NREL's work with IEEE Standards, visit www.nrel. gov/eis/awards.html.

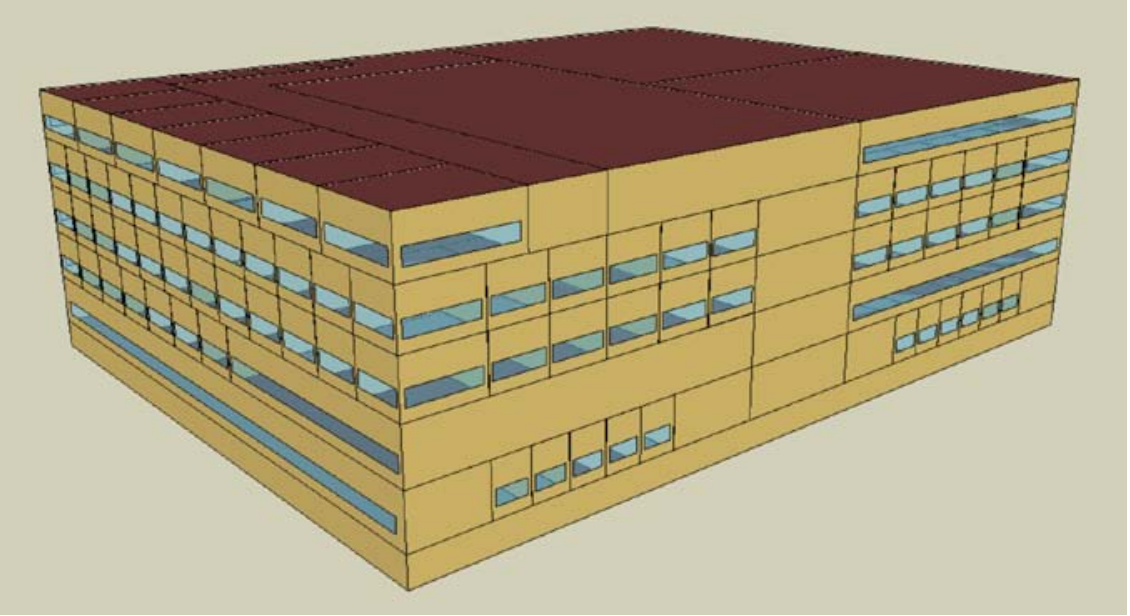

\section{Commercial Benchmark}

Building Models Make

\section{Energy Analysis Easier}

NREL recently released a comprehensive set of benchmark building models representing most of the commercial building stock and all of the climates in the United States.

NREL, working with Pacific Northwest National Laboratory and Lawrence Berkeley National Laboratory, led the development of these models, which provide a consistent baseline for evaluating the energy performance of buildings and systems. The models also:

- Simplify the energy simulation process

- Offer high-quality, well-vetted data about the benchmark buildings

- Save time for those in the building industry who could easily spend more than 100 hours creating a detailed baseline building model.

\section{Many Uses}

Several groups are interested in the benchmark building models. The American Society of Heating, Refrigerating and Air-Conditioning Engineers is planning to use the models as baselines for new
This rendering represents the hospital used to develop the commercial benchmark building models. It is one of 16 building types that NREL modeled to use as baselines in energy simulation.

standards. State energy initiatives also value the benchmarks. For example, the State of Minnesota has set a goal of carbon-neutral state-funded buildings by 2030 and is using the models to achieve

\section{"The benchmark building models, as well as the work NREL has done on energy simulation software, establish NREL as a key resource for those working to create more energy-efficient buildings."}

Ron Judkoff,

Program Manager, NREL Buildings

this goal. Manufacturers, building engineers, building scientists, and universities will all benefit from the models. Visit www.eere .energy.gov/ buildings/commercial_initiative/ benchmark_models.html to learn more. 


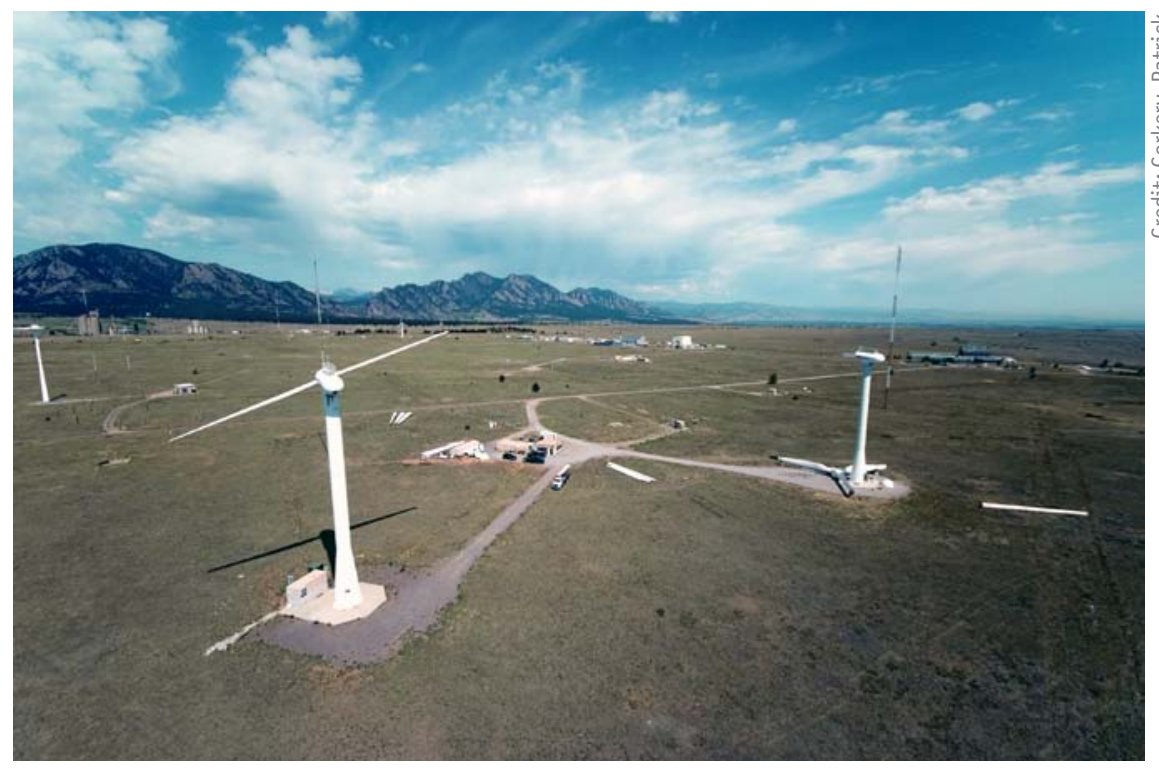

\section{Regional Wind Workshops Increase Technology \\ Acceptance}

Growing technology at the grassroots level. That's one way the Wind Powering America (WPA) Project at NREL's National Wind Technology Center (NWTC) works to increase wind energy acceptance and deployment. The goal of the project is to facilitate the installation of at least $100 \mathrm{MW}$ of wind energy in at least 30 states by 2010 from a baseline of eight states in 2002.

To achieve its goal, the project supports 33 state Wind Working Groups across the nation. As part of that effort, WPA facilitated workshops and conferences in six states during the first quarter of FY09: North Carolina, Virginia, West Virginia, Oklahoma, Kansas, and Nebraska.

WPA team members work with local Wind Working Groups to tailor the events to the very different needs of each region-from providing information on transmission requirements to addressing wildlife concerns. The team provides support for small, intimate workshops, such as those held in North
NREL's National Wind Technology Center supports 33 state Wind Working Groups across the nation to help increase wind energy acceptance and deployment.

Carolina and Virginia, as well as for larger conferences, such as the West Virginia Wind Working Group meeting for more than 50 stakeholders.

The team also worked with state Wind Working Groups to support the:

- Oklahoma first annual Wind Energy Conference in Oklahoma City in December 2008, featuring exhibitors, presenters, and keynote speaker T. Boone Pickens

- Kansas Wind Power Conference in Topeka in September 2008, which attracted about 750 people (Kansas recently celebrated its $1,000-\mathrm{MW}$ wind energy milestone)

- Nebraska Wind Power Conference in Kearney in November 2008, which drew almost 400 participants. Learn more about NREL's wind activities at/www.nrel.gov/wind/..

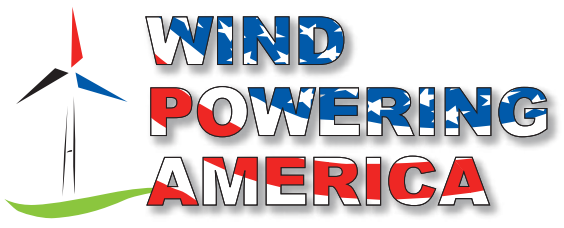

SolarTAC Allows Real-World Technology Demonstrations

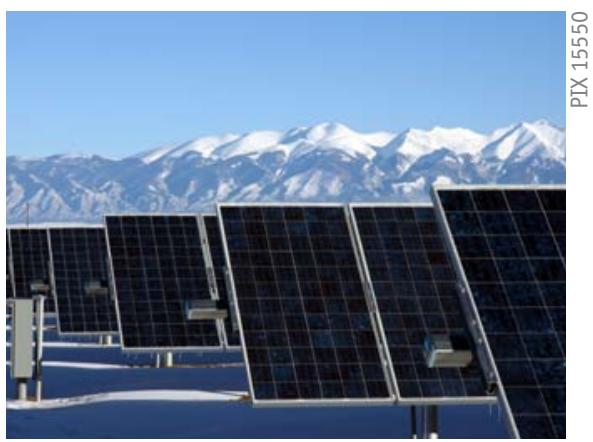

SolarTAC will help advance solar technology, making possible additional installations such as this SunEdison photovoltaic power plant near Alamosa, Colorado.

The nation's largest solar test sitethe Solar Technology Acceleration Center (SolarTAC) - will advance and accelerate the commercialization of solar technology, thanks to a partnership among NREL, the Midwest Research Institute (MRI), solar companies, public utilities, and Colorado universities.

SolarTAC will provide a facility to test and demonstrate the latest solar energy system components - particularly products nearing the commercial stage of development.

"Anyone interested in large-scale testing of solar energy system components can gain access to the site," said Michael Pacheco, NREL vice president of Deployment and Industrial Partnerships. "We will not exclude competitors. SolarTAC is based on a very open policy with respect to new members that is consistent with MRI's not-for-profit status and NREL's mission."

Visit www.nrel.gov/features/ 20081031_solartac.html..

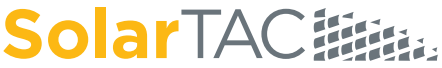

Technology Acceleration Center 


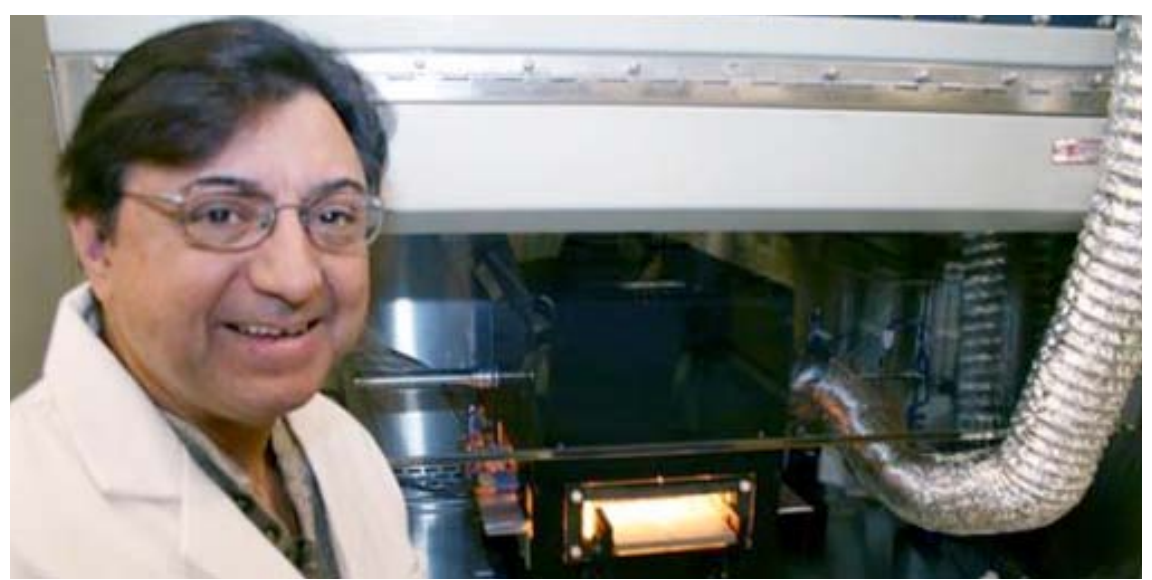

NREL's Optical Furnace: A Cheaper Way To Make Solar Cells

When NREL's Bhushan Sopori talks, members of the photovoltaics (PV) industry listen. Such is his reputation, based on 20-plus years of developing inventions such as reflectometers, defect-mapping systems, and optical furnaces for manufacturing PV cells.

The most recent optical furnace to come from Dr. Sopori's laboratory is highly energy efficient and reduces the energy payback time for solar cells. The NREL furnace has commanded the attention of Applied Optical Systems, a startup company. "We'd like to develop thinfilm silicon solar cells with higher efficiencies, up to $15 \%$ to $18 \%$, and we believe this furnace will enable us to do so," said A. Rangappan, the company's founder and CEO.

Rangappan also said it will take only a few minutes for this optical furnace

Energy Innovations is a publication of the National Renewable Energy Laboratory.

Managing editor: Robert Hawsey

Technical editor: Carol Anna

Designer: William Gillies

Visit our Web site at www.nrel.gov

If you have any comments or questions about this publication, please contact the NREL Public Affairs office at 303-275-4090.
NREL Principal Engineer Bhushan Sopori has fired up an advanced optical furnace he developed to fabricate solar cells efficiently.

to process a thin-film solar cell, which reduces manufacturing costs. Overall, he estimated the company's solar cell will cost around 80 cents per watt.

Applied Optical Systems and NREL have developed a partnership through a cooperative research and development agreement to construct an optical furnace system prototype geared toward the company's products.

And it doesn't stop with thin-film cells. Each type of solar cell or manufacturing process typically requires a different furnace configuration and temperature profile. But with this advanced optical furnace system, a solar cell manufacturer can "ask" the computer for any temperature profile needed for processing a solar cell, and the same type of furnace is suitable for several

National Renewable Energy Laboratory 1617 Cole Boulevard, Golden, Colorado 80401-3305

303-275-3000 • www.nrel.gov

NREL is a national laboratory of the U.S. Department of Energy, Office of Energy Efficiency and Renewable Energy, operated by the Alliance for Sustainable Energy, LLC.

NREL/BR-6A4-45227・ Revised July 2009

Printed with a renewable-source ink on paper containing at least $50 \%$ wastepaper, including $10 \%$ post consumer waste. solar cell fabrication process steps.

"In the future, solar cell manufacturers will only need this one optical furnace because it can be used for any process, including diffusion, metallization, and oxidation," Sopori said. "This helps reduce manufacturing costs."

Meanwhile, another partnership using the optical furnace has evolved between NREL and SiXtron Advanced Materials, which is also a startup. SiXtron plans to use the optical furnace to optimize its metallization process for novel antireflective solar cell coatings. Learn more about NREL's optical furnace at www.nrel.gov/technologytransfer/ news/2008/631.html.

\section{Deputy Assistant Secretary for Renewable Energy Jacques A. Beaudry- Losique Visits NREL}

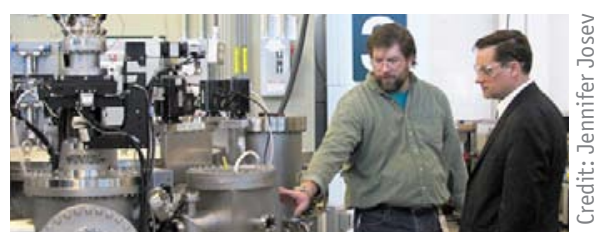

The amorphous silicon cluster tool, pictured above, captures the attention of the DOE Deputy Assistant Secretary for Renewable Energy (right). NREL Process Integration Engineer Steve Robbins provides explanation.

\section{DOE Deputy Assistant Secretary} for Renewable Energy Jacques A. Beaudry-Losique toured NREL's Process Development and Integration Laboratory (PDIL) in January. The PDIL offers collaborative resourcessuch as integrating tools, data, and materials - that enable technical experts from NREL, the solar industry, and universities to accelerate the growth of photovoltaic knowledge. Learn more by visiting www.nrel.gov/ pv/pdil/about_pdil.html.. 